\title{
Diketopiperazines and arylethylamides produced by Schizophyllum commune, an endophytic fungus in Alchornea glandulosa
}

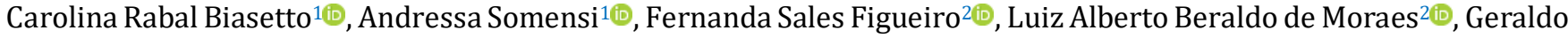

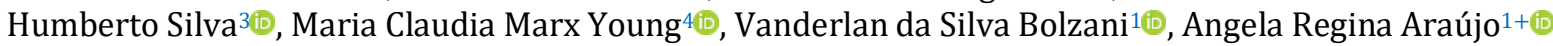

1 São Paulo State University (Unesp), Institute of Chemistry, 55 Prof. Francisco Degni Av., Araraquara, São Paulo, Brazil

2 University of São Paulo (USP), Faculty of Philosophy, Sciences and Letters, 3900 Bandeirantes Av., Ribeirão Preto, São Paulo, Brazil

3 Federal University of Viçosa (UFV), Institute of Science Exact and Technological, Peter Henry Rolfs Av., Viçosa, Minas Gerais, Brazil

4 São Paulo Institute of Botany, Nucleus of Research in Physiology and Biochemistry, 3687 Miguel Stéfano Av., São Paulo, São Paulo, Brazil

+Corresponding author: Angela Regina Araújo, email address: angela.araujo@unesp.br

\section{ARTICLE INFO}

Article history:

Received: December 5, 2018

Accepted: March 13, 2019

Published: July 4, 2019

\author{
Keywords: \\ 1. Endophytic fungi \\ 2. Schizophyllum commune \\ 3. Alchornea glandulosa \\ 4. diketopiperazines \\ 5. arylethylamides
}

ABSTRACT: Chemical investigation of the crude PDB extract obtained from the endophytic fungus Schizophyllum commune afforded the pure substances, cyclo( $L$-Pro- $L$-Val) (1), uracil (2), cyclo(Pro-Tyr) (3), $p$-hydroxybenzoic acid (4) and a mixture of Rel.cyclo(Pro-Phe) (5) and Rel.cyclo(Pro-Ile) (6). When cultured in corn, the extract of this fungus yielded $\mathrm{N}$-(2-phenylethyl) acetamide (7) and $\mathrm{N}$-(4hydroxyphenylethyl) acetamide (8). The structures of all compounds were determined based on the analyses of their MS, 1D and 2D-NMR spectroscopic data. Analysis of the crude extracts obtained from smallscale cultures (in PBD, YM, Nutrient, Czapek, Malt Extract, Corn and Rice) and a large-scale culture (in PDB) by mass spectrometry showed the presence of diketopiperazines $1,3,5$ and 6 . The crude extracts showed promising antioxidant, antifungal and acetylcholinesterase (AChE) inhibitory activities. The metabolites 7 and 8 showed antifungal and AChE inhibitory activities in vitro. This is the first report of the identification and isolation of diketopiperazines, arylethylamides, $p$-hydroxybenzoic acid in endophytic fungus of the Schizophyllum genus.

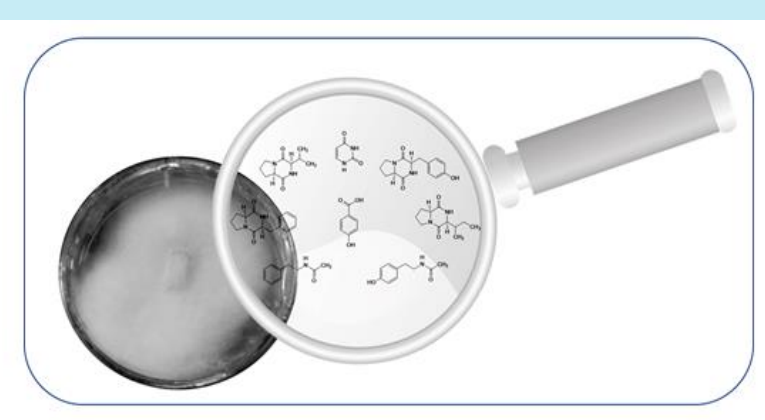

First report of the identification and isolation of diketopiperazines, arylethylamides and $p$-hydroxybenzoic acid in endophytic fungus of the Schizophyllum genus.

\section{Introduction}

Microorganisms as the endophytic fungi (endon $=$ inside; phyton $=$ plant) living asymptomatically in the intercellular space of host plants and establish a mutualistic relationship with its host during a part or all their life. These endophytes are found in parts of plants such as leaves, stems, fruits, seeds, and roots, and reside inside the plant all its life, being transmitted in some cases to future generations through seeds of the host ${ }^{1-4}$. The interactions established by endophytes may diversify from mutualism (endophyte and host plant obtain advantages) to parasitism (only the endophyte is benefited $)^{5,6}$. Most natural products isolated from endophytes showed antimicrobial activity, and in many cases, these have been implicated in protecting the host plant against phytopathogenic microorganisms. ${ }^{1,7,8}$ Studies in 2012 showed trichodermin and cercosporamide with strong antifungal and antitumor activities, which were isolated from endophyte belonging to the genus Phoma associated with Arisaema erubescens. ${ }^{9}$

Alchornea glandulosa (Euphorbiaceae) belongs to Brazilian Cerrado, which is well-known as 
sources of bioactive secondary metabolites ${ }^{10-13}$. Several chemical and pharmacological studies were performed with extracts and pure substances from this plant and presented promising results ${ }^{14-16}$. Several endophytic fungi were isolated from this plant, including $S$. commune, which were chemically and biologically investigated. $S$. commune is a filamentous fungus belonging to the class of Basiodiomicetos, known as a producer of pigments, antiviral, anticancer and immunomodulatory compounds ${ }^{17}$. From this endophyte were isolated phenolic compounds as gallic acid and L-ascorbic acid, both with antioxidant activity ${ }^{18}$. Diketopiperazines present biological activities such as antiviral, antifungal, antibacterial, insecticidal, antihyperglycemic agents, receptor affinities of calcium channels and serotonergic $^{19-21}$. Recent studies have demonstrated that diketopiperazine trans-cyclo(D-tryptophanylL-tyrosyl) presented low antiproliferative and cytotoxic effect with L-929 mouse fibroblast cells, K-562 leukemia cells and human HeLa Human cervix carcinoma $^{22}$. Several arylethylamides present phytotoxic potential ${ }^{23}$. Thus, this work reports isolation, structural elucidation and biological activities of these compounds.

\section{Materials and methods}

\subsection{General}

NMR spectra were carried out one-dimensional ${ }^{1} \mathrm{H}$ Varian INOVA-300 spectrometer operating at $300 \mathrm{MHz}$ for ${ }^{1} \mathrm{H}$ nucleus and TMS as internal reference. ${ }^{1} \mathrm{H}$ NMR spectra and ${ }^{13} \mathrm{C} 1 \mathrm{D}$ and $2 \mathrm{D}$ and NOESY 1D were performed on Varian INOVA500 spectrometer operating at $500 \mathrm{MHz}$ for ${ }^{1} \mathrm{H}$ nucleus and the nucleus $125 \mathrm{MHz}$ for ${ }^{13} \mathrm{C}$ and TMS as internal reference. Mass spectra of high and low resolution were obtained on a spectrometer of UltrOTOFQ - ESI-TOF Mass Spectrometer (Bruker Daltonics, Billerica, MA, USA). Analyses were performed on a mass spectrometer with Varian 1200L LC autosampler, and triplequadrupole electrospray ionization source (ESI). The mass spectra of low resolution were obtained on a LCQ Fleet spectrometer (Thermo Scientific) with electrospray ionization source (ESI). TLC was performed using Merck silica gel $60 \mathrm{G} \mathrm{F}_{254}$. Spots on TLC plates were visualized under UV light and by spraying with anisaldehyde- $\mathrm{H}_{2} \mathrm{SO}_{4}$ reagent followed by heating at $120{ }^{\circ} \mathrm{C}$. Analytical HPLC was performed on a Shimadzu (Shimadzu SPD-
M20A) with diode array ultraviolet (DAD) detector, using a Phenomenex Gemini analytical column (C-18) $(250$ x $4.60 \mathrm{~mm}, 5 \mu \mathrm{m})$. Preparative HPLC was performed on Varian ProStar device coupled to the ProStar UV-Vis detector, using Phenomenex Luna C-18 silica semi-preparative column $(150 \times 21.20 \mathrm{~mm} ; 5 \mu \mathrm{m})$. Optical rotation values were obtained at JASCO P-1020 polarimeter with sodium lamp, and $1.0 \mathrm{~mL}$ of cell Jasco Spectra Manager software.

\subsection{Fungal isolation and identification}

The traditional methodology ${ }^{24}$ was used for the isolation of the endophytic fungus $S$. commune from healthy leaves of Alchornea glandulosa. S. commune was identified by sequencing and phylogenetic analysis of ribosomal operon gene fragments (CPQBA-UNICAMP-Multidisciplinary Center for Agricultural and Biological Chemistry Research, Campinas, Brazil). DNA sequence of the ITS region was analyzed using the GenBank BLAST routine and the CBS database (Centraalbureau voor Schimmelcultures, Fungal Biodiversity Centre).

The phylogenetic tree constructed from the sequences retrieved in GenBank and analyzes based on molecular data allowed the identification of this fungus as Schizophyllum commune (Filo Basidiomycota, order Agaricales and family Schizophyllaceae). The sequence of the isolate showed $99-98 \%$ similarity to sequences from different $S$. commune isolates, including $S$. commune BCC22128 and DSM 1025. In addition, in the phylogenetic tree, the isolate formed a cluster with the S. commune PRJ21 and 1-84 isolates supported by a bootstrap value of $94 \%$. This endophytic fungus was stored in the NuBBE fungi collection in Araraquara, Brazil (kept in sterile water at $25{ }^{\circ} \mathrm{C}$ ) encoded as $\mathrm{Ag}-\mathrm{Sc}-02$ and in CPQBA as CPQBA 154-09 DRM.

\subsection{Cultivation}

\subsubsection{Different culture media (small scale)}

S. commune was grown in Petri plates containing PDA (potato starch $4 \mathrm{~g}$, dextrose $20 \mathrm{~g}$, agar $15 \mathrm{~g}, \mathrm{H}_{2} \mathrm{O} 1000 \mathrm{~mL}$ ) and incubated during ten days. After this period, this endophyte was cultivated in small scale in 2 Erlenmeyer flasks $(500 \mathrm{~mL})$ containing $300 \mathrm{~mL}$ of each liquid medium and these were autoclaved at $121{ }^{\circ} \mathrm{C}$ for 
20 min. S. commune was cultivated in different liquid culture media (PBD, YM, Nutrient, Czapek, Malt Extract) under agitation at $120 \mathrm{rpm}$, for 28 days at $25^{\circ} \mathrm{C}$. At the end of the incubation period, the broth was separated from the mycelium by filtration and the crude extracts were obtained by extraction with EtOAc ( $3 \times 50 \%$ of the broth volume each) and dried in rotatory evaporator, affording 49.2, 54.0, 26.7, 26.5 and $38.2 \mathrm{mg}$, respectively. The cultivation on solid medium was performed: rice and corn inoculated in 2 Erlenmeyer flasks (500 mL each), containing each one: $90 \mathrm{~g}$ of rice or corn in $75 \mathrm{~mL}$ of Milli-Q $\mathrm{H}_{2} \mathrm{O}$. The culture media were autoclaved three times (three consecutive days) at $121^{\circ} \mathrm{C}$ for $20 \mathrm{~min}$. The cultures were incubated at $25 \pm 2{ }^{\circ} \mathrm{C}$ for 21 days. At the end of the growth period, the solid cultures were ground and extracted with EtOAc $(5 \times 200$ $\mathrm{mL}$ ). The EtOAc fraction was subjected to liquidliquid partition with $\mathrm{H}_{2} \mathrm{O}$. The EtOAc extract concentrated was dissolved in $\mathrm{CH}_{3} \mathrm{CN}$ and then subjected to liquid-liquid partition with $\mathrm{C}_{6} \mathrm{H}_{14}$. The $\mathrm{CH}_{3} \mathrm{CN}$ fractions were evaporated to give $\mathrm{CH}_{3} \mathrm{CN}$ deffated extracts, affording 279.7 (rice) and 335.1 (corn) mg.

\subsubsection{PDB (large scale)}

S. commune was inoculated in 52 Erlenmeyer flasks of $500 \mathrm{~mL}$ (large scale), containing each one: $1.2 \mathrm{~g}$ of potato starch, $6.0 \mathrm{~g}$ dextrose (PDB) in $300 \mathrm{~mL}$ of Milli-Q $\mathrm{H}_{2} \mathrm{O}$, which were autoclaved at $121{ }^{\circ} \mathrm{C}$ for $20 \mathrm{~min}$. Approximately 5 small pieces $(1 \times 1 \mathrm{~cm})$ of PDA medium, from the Petri dish containing biomass of the $S$. commune isolated were inoculated into Erlenmeyer flasks, sealed with cotton, to permit aerobic growth, and incubated at $25 \pm 2{ }^{\circ} \mathrm{C}$ for 28 days. At the end of the incubation period, the cultures were combined, filtered, extracted with EtOAc $(3 \times 0.51)$. The solvent was evaporated, yielding a crude EtOAc extract (960 mg).

\subsection{Purification and identification of chemical constituents}

\subsubsection{Liquid medium (PDB)}

The EtOAc extract $(960.0 \mathrm{mg})$ was fractioned by $\mathrm{CC}$ using reversed-phase silica gel $(\mathrm{C}-18)$ and gradient of $\mathrm{H}_{2} \mathrm{O}: \mathrm{CH}_{3} \mathrm{OH}\left(15: 100 \% \mathrm{CH}_{3} \mathrm{OH}(\mathrm{v} / \mathrm{v})\right)$, resulting into eight fractions (S.co-F1-S.co-F8). The fraction S.co-F1 $(559.0 \mathrm{mg})$ was further fractioned using reversed-phase silica gel (C-18) and eluted with a $\mathrm{H}_{2} \mathrm{O}: \mathrm{CH}_{3} \mathrm{OH}$ gradient $(35: 100 \%$ $\mathrm{CH}_{3} \mathrm{OH}$ (v/v), giving rise to seven subfractions (S.co-F1.1-S.co-F1.7). The subfraction S.co-F1.1 $(470.0 \mathrm{mg}$ ) was fractioned by $\mathrm{CC}$ using reversedphase silica gel (C-18) and gradient of $\mathrm{H}_{2} \mathrm{O}: \mathrm{CH}_{3} \mathrm{OH}\left(5: 100 \% \quad \mathrm{CH}_{3} \mathrm{OH}(\mathrm{v} / \mathrm{v})\right)$, resulting into seventeen fractions (S.co-F1.1.1-S.coF1.1.17). Subfraction S.co-F1.1.2 was identified as cyclo(L-Pro-L-Val) (1) $(16.0 \mathrm{mg})$. The subfraction S.co-F1.1.9 $(2.0 \mathrm{mg})$ was analyzed by LC-MS (ACN: $\mathrm{H}_{2} \mathrm{O} \quad(05: 95-50: 50 \mathrm{v} / \mathrm{v}, 30$ '; 50:50-100:0 (v/v), 10'; 100:0-05:95 (v/v), 15'; $1 \mathrm{~mL} \mathrm{~min}^{-1} \mathrm{e}$ $\lambda=220 \mathrm{~nm}, \mathrm{C}-18$ column) and it was identified as cyclo(L-Pro-L-Val) (1), Rel.cyclo(Pro-Phe) (5) and Rel.cyclo(Pro-Ile) (6) $(2.0 \mathrm{mg})$ in mixture. The fraction $S . c o-F 1.1 .1(300.0 \mathrm{mg})$ was fractioned by $\mathrm{CC}$ using normal phase silica gel and gradient of $\mathrm{CHCl}_{3}: \mathrm{CH}_{3} \mathrm{OH}\left(2: 100 \% \mathrm{CH}_{3} \mathrm{OH}(\mathrm{v} / \mathrm{v})\right.$ with $1 \%$ HOAc), resulting into fifty-five fractions (S.coF1.1.1.1- S.co-F1.1.1.55). Subfraction S.coF1.1.1.46 was isolated as compound uracil (2) (1.5 $\mathrm{mg}$ ) and S.co-F1.1.1.38 was identified, in mixture, as cyclo(Pro-Tyr) (3) with $p$-hydroxybenzoic acid (4) $(2.2 \mathrm{mg})$.

\subsubsection{Solid medium (corn)}

The $\mathrm{CH}_{3} \mathrm{CN}$-deffated extract $(185.0 \mathrm{mg})$ was subjected to chromatography column (CC), normal phase (silica gel) by gradient elution with $\mathrm{C}_{6} \mathrm{H}_{14}$ :EtOAc (70:30) (1 to $25 \% \mathrm{CH}_{3} \mathrm{OH}$ ) affording into sixteen fractions (S.co-Mi1-S.co-Mi16). The subfractions S.co-Mi10 was identified as containing compound $\mathrm{N}$-(2-phenylethyl) acetamide (7) (18.0 mg) and S.co-Mi16 was found to contain compound $\mathrm{N}$-(4-hydroxyphenylethyl) acetamide (8) (20.0 mg).

\subsection{Identification of diketopiperazines in different crude extracts}

Analyses were performed on a mass spectrometer with Varian 1200L LC, direct insertion (ID) in positive mode. After the acquisition of information about protonated molecules by direct insertion, conducted experiments using MS-MS. Malt extract, Nutrient and YM (small scale) were subjected to MS-MS analysis in positive mode with application of $15 \mathrm{~V}$ collision energy.

2.6 Acetylcholinesterase inhibitory activity 
The crude extracts $\left(20 \mu \mathrm{g} \mathrm{uL}^{-1}\right)$ were eluted in TLC, being $\mathrm{CHCl}_{3}: \mathrm{CH}_{3} \mathrm{OH}$ (88:12) to the crude extract in liquid medium, Hexane: EtOAc (70:30) for the extracts in solid media. Compounds $\mathbf{7}$ and $\mathbf{8}$ $\left(5 \mu \mathrm{g} \mu \mathrm{L}^{-1}\right)$ were applied on TLC layers, followed by elution with Hexane:EtOAc $(70: 30, \mathrm{v} / \mathrm{v})$ and subsequent drying. The plates were then sprayed with enzyme solution $\left(6.66 \mathrm{U} \mathrm{mL}^{-1}\right)$, thoroughly dried and incubated at $37^{\circ} \mathrm{C}$ for $20 \mathrm{~min}$ (in a moist atmosphere). Enzyme activity was detected by spraying with a solution consisting of $0.25 \% 1$ naphthyl acetate in $\mathrm{CH}_{3} \mathrm{CH}_{2} \mathrm{OH}$ containing $0.25 \%$ Fast Blue B salt (in aqueous solution). Potential acetylcholinesterase inhibitors appeared as clear zones on a purple-colored background. Electric eel AChE type V (product no. C 2888, $1000 \mathrm{U}$ ) and the other reagents were purchased from SigmaAldrich. The positive standard for comparison was physostigmine $\left(0,05 \mu \mathrm{g} \mathrm{mL}^{-1}\right)^{25}$.

\section{7 $\mathrm{DPPH}^{*}$ scavenging capacity assay}

Applied in microplates 96-well: $200 \mu \mathrm{L}$ of DPPH $\left(4 \mathrm{mg} \mathrm{mL}^{-1}\right.$ in $\left.\mathrm{CH}_{3} \mathrm{OH}\right)$ and $100 \mu \mathrm{L}$ of the samples at 7 different concentrations. Positive Control: $200 \mu \mathrm{L}$ of DPPH and $100 \mu \mathrm{L}$ of the standard antioxidant (quercetin and rutin). Negative control: $200 \mu \mathrm{L}$ of DPPH and $100 \mu \mathrm{L}$ of solvent. The microplate was kept for 30 minutes in the dark. The evaluation of the reduced form of DPPH generated by reading the absorbance at $\lambda=$ $517 \mathrm{~nm}^{26}$.

\subsection{Evaluation of antifungal activity}

The crude extracts $\left(40 \mu \mathrm{g} \mathrm{uL}^{-1}\right)$ were eluted in TLC, being $\mathrm{CHCl}_{3}: \mathrm{CH}_{3} \mathrm{OH}$ (88:12) to the crude extract in liquid medium, Hexane: EtOAc $(70: 30 \mathrm{v} / \mathrm{v})$ for the extracts in solid media. Compounds 7 and $8\left(10 \mu \mathrm{g} \mu \mathrm{L}^{-1}\right)$ were applied on TLC layers, followed by elution with Hexane:EtOAc (70:30) and subsequent drying. The TLC layers were nebulized with the phypathogenic fungus Cladosporium cladosporioides (Fresen) and C. sphaerospermum (Perzig) SPC 491 (concentration of $5 \times 10^{7}$ spores $\mathrm{mL}^{-1}$ in glucose solution and salts). The plates were incubated at $25^{\circ} \mathrm{C}$ for 48 hours in absence of light. The positive standard for comparison was nystatin $(1 \mu \mathrm{g})^{27}$.

\section{Results and discussion}

The AcOEt extract of $S$. commune (PDB and corn) afforded compounds 1-8 (Figure 1) by using a combination of reversed (C-18) and normal phase (silica gel) chromatography. ${ }^{1} \mathrm{H}$ NMR and LC-MS analysis allowed to elucidate and identify the pure substances or in mixtures.

The known compounds cyclo(L-Pro-L-Val) (1), uracil (2), cyclo(Pro-Tyr) (3), p-hydroxybenzoic acid (4), Rel.cyclo(Pro-Phe) (5), Rel.cyclo(Pro-Ile) (6), N-(2-phenylethyl) acetamide (7) and N-(4hydroxy phenylethyl) acetamide (8) were identified by comparing its spectroscopic data with literature values 23,28-33. The spectrometric data ${ }^{1} \mathrm{H}$ NMR and MS of the culture medium without $S$. commune were compared with the spectra of the compound and showed no similarity.

The substance 7 showed low potential to inhibit the enzyme acetylcholinesterase and strong activity against $C$. cladosporioides. The substance $\mathbf{8}$ showed moderate potential to inhibit the enzyme acetylcholinesterase and weak activity against $C$. cladosporioides and C. sphaerospermum.

The crude extracts showed promising results for biological assays as antioxidant, highlighting the Malt Extract with a significant $\mathrm{DPPH}^{\circ}$ sequestration rate of $68.36 \%$ and $\mathrm{IC}_{50}=$ $28.7 \mu \mathrm{g} \mathrm{mL}^{-1}$, compared to $\mathrm{IC}_{50}=7.49 \mu \mathrm{g} \mathrm{L}^{-1}$ standard quercetin. The majority these extracts exhibited strong antifungal activity against the phytopathogenic fungi $C$. cladosporioides and $C$. sphaerospermum. The crude extracts displayed moderate AChE inhibitory activity. Unfortunately, the substances responsible by these bioactivities were not isolated.

The diketopiperazines $\mathbf{1}, \mathbf{3}, \mathbf{5}$ and $\mathbf{6}$ were detected in PDB extract (small scale) by MS. The crude extracts obtained from YM, Nutrient and Malt were subjected to MS-MS analysis and indicated the presence of diketopiperazines $\mathbf{1}, \mathbf{5}$ and 6. Analysis of crude extracts by direct insertion (ID), showed the protonated diketopiperazines and their fragments in five crude extracts by MS-MS experiment, which corroborate with the fragmentation characteristic of diketopiperazines isolated or identified in mixture.

In the crude extracts Czapek, rice $\left(\mathrm{CH}_{3} \mathrm{CN}\right)$ and corn $\left(\mathrm{CH}_{3} \mathrm{CN}\right)$ (small scale) the diketopiperazines were not identified, suggesting that the enzymes responsible by the biosynthesis of these compounds were not expressed by S. commune, in these media. With these observations was possible to confirm that the culture media influences the microorganisms metabolic production. 
cyclo(L-Pro-L-Val) (1)

ESIMS $m / z$ 197.0 $[\mathrm{M}+\mathrm{H}]^{+}$and fragments: 169.0 $[\mathrm{M}+\mathrm{H}-28]^{+}, 124.5[\mathrm{M}+\mathrm{H}-73]^{+}, 70.0[\mathrm{M}+\mathrm{H}-127]^{+}$.

cyclo(L-Pro-L-Tyr) (3)

ESIMS $\mathrm{m} / \mathrm{z} 261.3[\mathrm{M}+\mathrm{H}]^{+}$and fragments: 233.0 $[\mathrm{M}+\mathrm{H}-28]^{+}, 121.0 \quad[\mathrm{M}+\mathrm{H}-140]^{+}, 136.0 \quad[\mathrm{M}+\mathrm{H}-$ $125]^{+}, 70.3[\mathrm{M}+\mathrm{H}-191]^{+}$.

Rel.cyclo(Pro-Phe) (5)

ESIMS $m / z 245.5[\mathrm{M}+\mathrm{H}]^{+}$and fragments: 217.0

$[\mathrm{M}+\mathrm{H}-28]^{+}, 154.1[\mathrm{M}+\mathrm{H}-90]^{+}, 70.0[\mathrm{M}+\mathrm{H}-175]^{+}$.

Rel.cyclo(Pro-Ile) (6)

ESIMS $m / z 211.5[\mathrm{M}+\mathrm{H}]^{+}$and fragments: 183.0 $[\mathrm{M}+\mathrm{H}-28]^{+}, 137.8[\mathrm{M}+\mathrm{H}-73]^{+}, 114.1[\mathrm{M}+\mathrm{H}-97]^{+}$, $69.6[\mathrm{M}+\mathrm{H}-141]^{+}$.

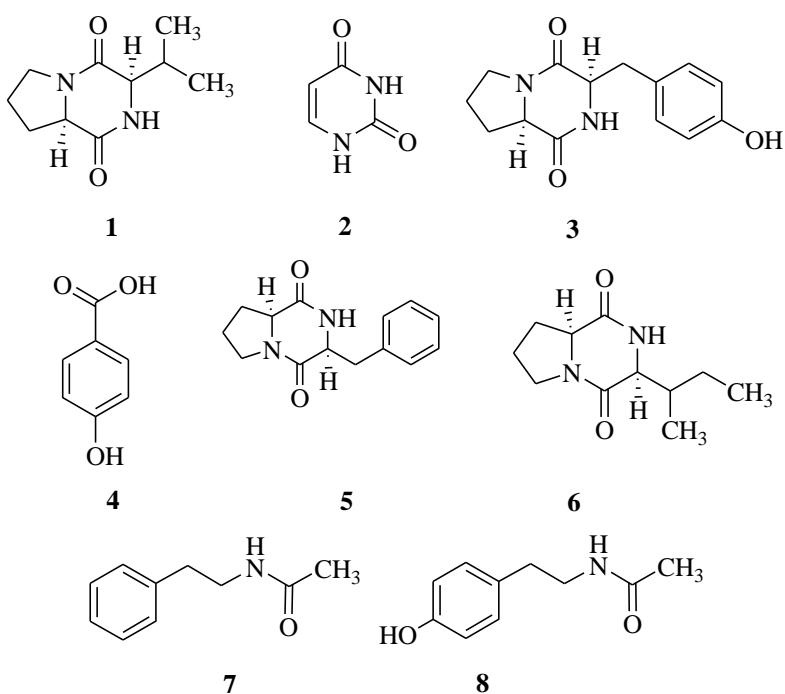

Figure 1. Compounds produced by the endophytic fungus $S$. commune.

\section{Conclusions}

The present study was designed to be the most comprehensive investigation of chemical constituents in S. commune. This is the first report of the identification and isolation of diketopiperazines, arylethylamides, $\quad p$ hydroxybenzoic acid in endophytic fungus of the Schizophyllum genus. Diketopiperazines was observed by mass spectrometry in the different crude extracts in small scale and PDB large scale, indicating this endophyte as a prolific producer of class of compounds by variation of nutrients of culture media. The biological activities reported by the compounds produced by $S$. commune suggest an ecological interaction, as well as in the plant protection as a defense mechanism of other organisms that inhabit the plant species.

These results reinforce the potential of these microorganisms as sources of secondary metabolites and collaborating with understanding the endophytic interaction and its host plant.

First attempts made to correlate variations in bands assigned as carbonyl stretching frequencies in the infrared region for solid metal ion complexes with the stability constants of these same complexes in solution date back to early 1950s.

\section{References}

[1] Gunatilaka, A. A. L., Natural products from plantassociated microorganisms: distribution, structural diversity, bioactivity, and implications of their occurrence, J. Nat. Prod. 69 (3) (2006) 509-526. https://doi.org/10.1021/np058128n.

[2] Rodriguez, R. J., White Jr. J. F., Arnold, A. E., Redman, R. S., Fungal endophytes: diversity and functional roles, New Phytologist 182 (2) (2009) 314330. https://doi.org/10.1111/j.1469-8137.2009.02773.x.

[3] Tan, R. X., Zou, W. X., Endophytes: a rich source of functional metabolites, Nat. Prod. Rep. 18 (8) (2001) 448-459. https://doi.org/10.1039/B100918O.

[4] Kusari, S., Pandey, S. P., Spiteller, M., Untapped mutualistic paradigms linking host plant and endophytic fungal production of similar bioactive secondary metabolites, Phytochemistry 91 (2013) 81-87. https://doi.org/10.1016/j.phytochem.2012.07.021.

[5] Bae, H., Sicher, R. C.; Kim, M. S., Kim, S-H.; Strem, M. D., Melnick, R. L., Bailey, B. A., The beneficial endophyte Trichoderma hamatum isolate DIS 219b promotes growth and delays the onset of the drought response in Theobroma cacao, J. Exp. Bot. 60 (11) (2009) 3279-3295. https://doi.org/10.1093/jxb/erp165.

[6] Kusari, P., Kusari, S., Spiteller, M., Kayser, O., Implications of endophyte-plant crosstalk in light of quorum responses for plant biotechnology, Appl. Microbiol. Biotechnol. 99 (13) (2015) 5383-5390. https://doi.org/10.1007/s00253-015-6660-8.

[7] Gutierrez, R. M. P., Gonzalez, A. M. N., Ramirez, A. M., Compounds derived from endophytes: a review of phytochemistry and pharmacology, Curr. Med. $\begin{array}{lllll}\text { Chem. } & 19 & \text { (18) 2992-3030. }\end{array}$ https://doi.org/10.2174/092986712800672111. 
[8] Kusari, S., Spiteller, M., Are we ready for industrial production of bioactive plant secondary metabolites utilizing endophytes? Nat. Prod. Rep. 28 (7) (2011) 1203-1207. https://doi.org/10.1039/c1np00030f.

[9] Wang, L. W., Xu, B. G., Wang, J. Y., Su, Z. Z., Lin, F. C., Zhang, C. L., Kubicek, C. P., Bioactive metabolites from Phoma species, an endophytic fungus from the Chinese medicinal plant Arisaema erubescens, Appl. Microbiol. Biot 93 (3) (2012) 1231-1239. https://doi.org/10.1007/s00253-011-3472-3.

[10] Bolzani, V. S., Trevisan, L. M. V., Young, M. C. M., Caffeic acid esters and triterpenes of Alibertia macrophyla. Phytochemistry 30 (6) (1991) 2089-2091. https://doi.org/10.1016/0031-9422(91)85077-D.

[11] Young, M. C. M., Braga, M. R., Dietrich, S. M. C., Gottlieb, H. E., Trevisan, L. M. V., Bolzani, V. S., Fungitoxic non-glycosidic iridoids from Alibertia macrophylla, Phytochemistry 31 (10) (1992) 34333435. https://doi.org/10.1016/0031-9422(92)83701-Y.

[12] Silva, V. C., Faria, A. O., Bolzani, V. S., Lopes, M. N., A new ent-kaurane diterpene from stems of Alibertia macrophylla K. SCHUM. (Rubiaceae), Helv. Chim.

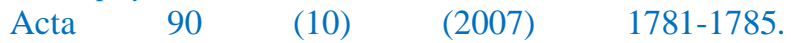
https://doi.org/10.1002/hlca.200790187.

[13] Junior, C. V., Pivatto, M., Rezende, A., Hamerski, L., Silva, D. H. S., Bolzani, V. S., (-)-7Hydroxycassine: a new 2,6-dialkylpiperidin-3-ol alkaloid and other constituents isolated from flowers and fruits of Senna spectabilis (Fabaceae), J. Braz. Chem. $\begin{array}{llll}\text { Soc. } & 24 & \text { (2) } & \text { (2013) }\end{array}$ https://doi.org/10.5935/0103-5053.20130029.

[14] Calvo, T. R., Lima, Z. P., Silva, J. S., Ballesteros, K. V. R., Pellizzon, C. H., Hiruma-Lima, C. A., Tamashiro, J., Brito, A. R. M. S., Takahira, R. K., Vilegas, W., Constituents and antiulcer effect of Alchornea glandulosa: activation of cell proliferation in gastric mucosa during the healing process, Biol. Pharm. $\begin{array}{lllll}\text { Bull. } & 30 & \text { (3) } & \text { (2007) 451-459. }\end{array}$ https://doi.org/10.1248/bpb.30.451.

[15] Conegero, L. S., Ide, R. M., Nazari, A. S., Sarragiotto, M. H., Filho, B. P. D., Nakamura, C. V., Carvalho, J. E., Foglio, M. A., Constituintes químicos de Alchornea glandulosa (Euphorbiaceae), Quím. Nova 26 (6) (2003) 825-827. https://doi.org/10.1590/S010040422003000600008 .

[16] Lopes, F. C. M., Rocha, A., Pirraco, A., Regasini, L. O., Silva, D. H. S., Bolzani, V. S., Azevedo, I., Carlos, I. Z., Soares, R., Anti-angiogenic effects of pterogynidine alkaloid isolated from Alchornea glandulosa, BMC Complem. Altern. M. 9 (15) (2009). https://doi.org/10.1186/1472-6882-9-15.

[17] Kumari, M., Survase, S. A., Singhal, R. S., Production of schizophyllan using Schizophyllum commune NRCM, Bioresource Technol. 99 (5) (2008) 1036-1043.

https://doi.org/10.1016/j.biortech.2007.02.029.

[18] Tripathi, A. M., Tiwary, B. N., Biochemical constituents of a wild strain of Schizophyllum commune isolated from Achanakmar-Amarkantak Biosphere Reserve (ABR), India, World Journal of Microbiology and Biotechnology 29 (8) (2013) 1431-1442. https://doi.org/10.1007/s11274-013-1306-4.

[19] Martins, M. B., Carvalho, I., Diketopiperazines: biological activity and synthesis, Tetrahedron 63 (40) (2007) 9923-9932. https://doi.org/10.1016/j.tet.2007.04.105.

[20] Gendy, B. D. M., Rateb, M. E., Antibacterial activity of diketopiperazines isolated from a marine fungus using $t$-butoxycarbonyl group as a simple tool for purification, Bioorg. Med. Chem. Lett. 25 (15) (2015) 3125-3128. https://doi.org/10.1016/j.bmcl.2015.06.010.

[21] Sathya, A., Vijayabharathi, R., Kumari, B. R., Srinivas, V., Sharma, H. C., Sathayadevi, P., Gopalakrishnan, S., Assessment of a diketopiperazine, cyclo(Trp-Phe) from Streptomyces griseoplanus SAI 25 against cotton bollworm, Helicoverpa armigera (Lepidoptera: Noctuidae), Appl. Entomol. Zool. 51 (1) (2016) 11-20. https://doi.org/10.1007/s13355-0150366-3.https://doi.org/10.1007/s13355-015-0366-3

[22] Ivanova, V., Laatsch, H., Kolarova, M., Aleksieva, K., Structure elucidation of a new natural diketopiperazine from a Microbispora aerata strain isolated from Livingston Island, Antarctica, Nat. Prod. Res. $27 \quad$ (2) (2013) 164-170. https://doi.org/10.1080/14786419.2012.665911.

[23] Maskey, R. P., Asolkar, R. N.; Kapaun, E., WagnerDöbler, I., Laatsch, H., Phytotoxic arylethylamides from limnic bacteria using a screening with microalgae, J. $\begin{array}{lllll}\text { Antibiotics } & 55 & \text { (7) } & \text { (2002) 643-649. }\end{array}$ https://doi.org/10.7164/antibiotics.55.643.

[24] Teles, H. L., Silva, G. H., Castro-Gamboa, I., Bolzani, V. S., Pereira, J. O., Costa-Neto, C. M., Eberlin, M. N., Young, M. C. M., Araújo, A. R., Benzopyrans from Curvularia sp., an endophytic fungus associated with Ocotea corymbosa (Lauraceae), Phytochemistry 66 (19) 2363-2367. https://doi.org/10.1016/j.phytochem.2005.04.043. 
[25] Marston, A., Kissling, J., Hostettmann, K., A rapid TLC bioautographic method for the detection of acetylcholinesterase and butyrylcholinesterase inhibitors in plants, Phytochem. Analysis 13 (1) (2002) 51-54. https://doi.org/10.1002/pca.623.

[26] Pauletti, P. M., Castro-Gamboa, I., Silva, D. H. S., Young, M. C. M., Tomazela, D. M., Eberlin, M. N., Bolzani, V. S., New antioxidant C-glucosylxanthones from the stems of Arrabidaea samydoides, J. Nat. Prod. $66 \quad(10) \quad$ (2003) $1384-1387$. https://doi.org/10.1021/np030100t.

[27] Rahalison, L., Hamburger, M., Hostettmann, K., Monod, M., Frenk, E., A bioautographic agar overlay method for the detection of antifungal compounds from higher plants, Phytochem. Analysis 2 (5) (1991) 199203. https://doi.org/10.1002/pca.2800020503.

[28] Fdhila, F., Vázquez, V., Sánchez, J. L., Riguera, R., DD-Diketopiperazines: antibiotics active against Vibrio anguillarum isolated from marine bacteria associated with cultures of Pectenmaximus, J. Nat. Prod., 66 (10) (2003) 1299-1301. https://doi.org/10.1021/np030233e.

[29] Jayatilake, G. S., Thornton, M. P., Leonard, A. C., Grimwade, J. E., Baker, B. J., Metabolites from an Antarctic sponge-associated bacterium, Pseudomonas aeruginosa, J. Nat. Prod. 59 (3) (1996) 293-296. https://doi.org/10.1021/np960095b.

[30] Lin, Z. J., Lu, X. M., Zhu, T. J., Fang, Y. C., Gu, Q. Q., Zhu, W., GPR12 Selections of the metabolites from an endophytic Streptomyces sp. associated with Cistanches deserticola, Arch Pharm. Res. 31 (1108) (2008) 1108-1114. https://doi.org/10.1007/s12272-0011276-4.

[31] Marinho, A. M. R., Marinho, P. S. B., Rodrigues, E. F., Chemical components of Penicillium sp, an endophytic fungus from Murraya paniculata (Rutaceae), Revista Ciências Exatas e Naturais 9 (2) (2007) 189-199. https://revistas.unicentro.br/index.php/RECEN/article/v iew/80.

[32] Takaya, Y., Furukawa, T., Miura, S., Akutagawa, T., Hotta, Y., Ishikawa, N., Niwa, M., Antioxidant constituents in distillation residue of awamori spirits, J. Agric. Food Chem. 55 (1) (2007) 75-79. https://doi.org/10.1021/jf062029d.

[33] Wang, G., Dai, S., Chen, M., Wu, H., Xie, L., Luo, X., Li, X., Two diketopiperazine cyclo(pro-phe) isomers from marine bacteria Bacillus subtilis sp. 13-2, Chem. Nat. Compd. $46 \quad$ (4) (2010) 583-585. https://doi.org/10.1007/s10600-010-9680-8. 